\title{
The Quality of Spermatozoa of Gembrong Goats during Cryopreservation Process
}

\author{
F. A. Pamungkas ${ }^{\mathrm{a}, *}$, A. Batubara ${ }^{\mathrm{a}}$, \& Sutoro $^{\mathrm{b}}$ \\ ${ }^{a}$ Goats Research Station Sei Putih, Indonesian Agency for Agricultural Research and Development (IAARD), \\ Ministry of Agriculture \\ Po Box. I Galang Deli Serdang, North Sumatera Utara 20585, Indonesia \\ 'Indonesian Center for Agricultural Biotechnology and Genetic Resource Research and Development (ICABIOGRD), \\ Indonesian Agency for Agricultural Research and Development (IAARD), Ministry of Agriculture \\ Jln. Tentara Pelajar 3A, Bogor 16111, Indonesia \\ (Received 16-04-2014; Reviewed 02-06-2014; Accepted 14-07-2014)
}

\begin{abstract}
Gembrong goat is an Indonesia local goat having specific characteristic that is currently categorized as a breed that is at risk of extinction. In this context, the cryopreservation of gametes is important to support a genome resource bank for storage of gametes for an indefinite period of time. Evaluation of semen and spermatozoa quality was performed to determine the survival of spermatozoa and this information will be used as a reference in the cryopreservation of semen and spermatozoa. The aim of this experiment was to study the characteristics of Gembrong goat's semen and spermatozoa during cryopreservation process. Once a week, semen from three Gembrong goats (ages about 2-3 years old) was collected using artificial vagina and then frozen with TRIS extender. After freezing, the semen was thawed. Macro- and microscopic parameters of semen and spermatozoa were assessed in fresh and frozen-thawed semen. Results showed that in the fresh semen, the volume was $0.5 \mathrm{~mL}$, sperm abnormalities was $5.74 \%$, sperm concentration was $6731 \times 10 \% \mathrm{~mL}$, the sperm motility was $78.33 \%$, live sperm was $83.17 \%$, and sperm membrane integrity was $78.53 \%$. After-thawing observation showed that sperm motility decreased to $49 \%(P<0.05)$ that was lower as compared to that in the fresh and post-equilibration semen. Similarly, the percentage of sperm viability and membrane integrity during cryopreservation showed a similar pattern with the sperm motility. In conclusion, the fresh semen of Gembrong goat had a good quality and met the requirement for further cryopreservation process. Similarly, the quality of frozen-thawed semen of Gembrong goat is eligible for artificial insemination (AI) or in vitro embryo production.
\end{abstract}

Key words: gembrong goats, sperm cryopreservation, sperm quality

\section{ABSTRAK}

Kambing Gembrong merupakan salah satu jenis kambing Indonesia yang memiliki penampilan yang spesifik dengan status terancam punah. Kriopreservasi spermatozoa diperlukan sebagai usaha pembentukan bank sperma dalam rangka menyelamatkan materi genetik hewan jantan dikarenakan pemanfaatannya dalam jangka panjang. Evaluasi kualitas spermatozoa dilakukan untuk menentukan daya hidup spermatozoa dan digunakan sebagai acuan dalam kriopreservasi spermatozoa. Tujuan penelitian adalah untuk mengetahui karakteristik spermatozoa kambing Gembrong selama proses kriopreservasi. Sebanyak 3 ekor kambing Gembrong yang berumur 2-3 tahun ditampung semennya satu kali seminggu menggunakan vagina buatan, dibekukan dengan pengencer TRIS, lalu di-thawing. Evaluasi karakteristik spermatozoa, baik makroskopik maupun mikroskopik, dilakukan pada semen segar, pascaekuilibrasi, dan pasca-thawing. Hasil penelitian menunjukkan bahwa volume semen segar adalah $0,5 \mathrm{~mL}$; abnormalitas $5,74 \%$; konsentrasi $6731 \times 10^{6} / \mathrm{mL}$; motilitas $78,33 \%$; viabilitas $83,17 \%$; dengan integritas membran $78,53 \%$. Setelah thawing, motilitas spermatozoa mengalami penurunan yang cukup drastis menjadi $49 \%$ dan secara nyata $(P<0,05)$ lebih rendah dibandingkan pada tahap segar dan ekuilibrasi. Demikian pula pada persentase viabilitas dan integritas membran spermatozoa selama kriopreservasi menunjukkan pola yang sama dengan motilitas. Disimpulkan bahwa kambing Gembrong memiliki kualitas spermatozoa yang baik dan memenuhi syarat untuk proses kriopreservasi. Demikian pula karakteristik spermatozoa kambing Gembrong selama proses kriopreservasi dan post thawing masih layak digunakan untuk inseminasi buatan (IB) atau produksi embrio in vitro.

Kata kunci : kambing gembrong, kriopreservasi, spermatozoa, kualitas spermatozoa 


\section{INTRODUCTION}

Goat is one of the biodiversity resources in Indonesia that has a potential to be developed and conserved as a meat-producing animal. Goat is one of the animal breeds that contribute in food supply, especially in animal-protein production, for human consumption (Handiwirawan et al., 2007). In Indonesia, it is reported that at least there are 13 breeds of goat, both local and crossed bred goats, which are distributed in all Indonesian archipelago. Gembrong goat is one of goat breeds having specific characteristics. In Indonesia, this breed of goat is only found in Bali, mainly in Karangasem Regency. The existence of this breed contributes to biodiversity in Bali so that this breed of goat is needed to be conserved as a local asset. There is no available scientific data as a reference to the origin of this goat (Zein et al., 2012).

However, for the time being, population of Gembrong goat is decrease continuously so that if it is not handled seriously, it would end up in a distinction that would cause a loss of animal-genetic resources. Some factors causing the drastic decrease in population of Gembrong goat is an extensive management system that is only grazed with the very minimum maintenance without a good disease control and reproduction program (Oka et al., 2011). In addition, another problem that is frequently happened in the field is the predation by forest dogs that frequently predate the goat in the evening. These factors cause the critical status and even can cause an extinction of the local goat (Oka et al., 2011). In addition, the genetic materials of the animal could be lost any time due to the unexpected mortality of the goat, the low libido, or the problem in the reproductive tract (Drouineaud et al., 2003; Kaabi et al., 2003). The loss of genetic material of Gembrong goat will affect the local animal biodiversity because the lost is irreversible and the genetic potential of Gembrong goat is still unknown.

The effort that can be done to avoid the loss of genetic materials of the animals is by conserving and saving the genetic materials so it can be used in the future for artificial breeding by a technology-assisted application. One of effort that can be used in preserving and conserving germ plasma of male animals is by cryopreservation of the semen or spermatozoa. Cryopreservation of semen or spermatozoa is a technique to preserve and store the spermatozoa in a frozen condition (at $-196{ }^{\circ} \mathrm{C}$ temperature) that involves some factors such as a correct extender, the process of semen dilution, the speed of cooling, freezing, and thawing in addition to the understanding of spermatozoa physiology and the quality of semen and spermatozoa in certain animal species (Purdy, 2006). Cryopreservation is a method that can be used to support the conservation of animal's genetic materials by freezing the semen and the use of the conserved semen and spermatozoa is not limited by geographical distance and time (Martins et al., 2007).

Evaluation of sperm quality is conducted to document the viability of the spermatozoa after cryopreservation and to standardize a technique for cryopreservation of semen and spermatozoa and its application for the technology-assisted animal reproduction such as artificial insemination. Therefore, this study was conducted to study the characteristics of semen and spermatozoa of Gembrong goat in fresh condition at the time of semen collection and after cryopreservation process.

\section{MATERIALS AND METHODS}

The experiment was conducted in the Reproduction Laboratory of Loka Penelitian Kambing Potong Sei Putih, North Sumatera Utara. Three pure breed male Gembrong goats, aged 2-3 yr and weight ranged 35$40 \mathrm{~kg}$, obtained from the ex situ collection in Loka Penelitian Kambing Potong were used in the experiment. The experimental goats were maintained in the individual cage with feeder and drinking water. Feed was provided in the form of concentrate and grass. Concentrated was given in the morning feeding around $300-500$ g per goat per day and fresh grass was given at noon and in the afternoon with the total of 3-4 $\mathrm{kg}$ per goat per day. Drinking water was provided ad libitum.

\section{Semen Collection and Cryopreservation}

The semen was collected from each male Gembrong goat once a week (1 ejaculate for each collection period) with 5 wk replications. Semen collection was conducted by using artificial vagina with inner liner and was filled with water with temperature of $40-42{ }^{\circ} \mathrm{C}$. The artificial vagina was filled with air by valve and was coated with lubricant with the deep of not more than $3 \mathrm{~cm}$ so that the artificial vagina had the similar condition with the real vagina. At the other end of the artificial vagina, the tube was set up for semen collection. The collected fresh semen was then evaluated for further processing.

Cryopreservation was conducted by using extender with composition of $2.96 \mathrm{~g}$ Tris amino methane, 1.65 $\mathrm{g}$ citric acid, $2.16 \mathrm{~g}$ lactose, $6 \mathrm{~mL}$ glycerol, $1000 \mathrm{IU} / \mathrm{mL}$ penicillin, $1000 \mu \mathrm{g} / \mathrm{mL}$ streptomycin, $20 \mathrm{~mL}$ egg yolk, and $100 \mathrm{~mL}$ aquabidest ad (Kostaman et al., 2000). After dilution, the final sperm concentration of semen after dilution was $100 \times 10^{6} / \mathrm{mL}$, and was then equilibrated at temperature of $5{ }^{\circ} \mathrm{C}$ for $2 \mathrm{~h}$. Then, the semen was put into a straw with the size of $0.25 \mathrm{~mL}$ (IMV, France), and then was put in a styrofoam plate in the liquid nitrogen steam for $20 \mathrm{~min}$ (around $4 \mathrm{~cm}$ from the surface of the liquid nitrogen) and then soon was put into a liquid nitrogen container for storage. The thawing was conducted by placing the straw of frozen semen in the air at room temperature for 30 seconds and then it was dipped in the water bath at $37{ }^{\circ} \mathrm{C}$ for $30 \mathrm{~s}$. The characteristics of semen and spermatozoa were evaluated after thawing.

\section{Parameters Observed}

Parameters observed were (1) the macroscopic characteristics of fresh semen (volume, color, consistency, and $\mathrm{pH}$ ) and microscopic characteristics of spermatozoa (motility, membrane integrity, viability, and abnormality), (2) The spermatozoa quality during cryopreserva- 
tion process, i.e., motility, viability, and membrane integrity. The $\mathrm{pH}$ was measured by using $\mathrm{pH}$-indicator paper 6.4-8.0 (Merck).

\section{Data Analysis}

The data on the characteristics of fresh semen and spermatozoa were analyzed by average test, while the data on the quality of spermatozoa during cryopreservation were analyzed by analysis of variance. If there was a difference between groups then the analysis was continued with Duncan's Multiple Range Test (DMRT) according to Steel \& Torrie (1993). The data were processed by using SPSS version 19.

\section{RESULTS AND DISCUSSION}

\section{Characteristics of Fresh Spermatozoa of Gembrong Goats}

The observation of fresh semen and spermatozoa characteristics of Gembrong goat was conducted to test whether the semen is feasible to be processed for cryopreservation or freezing and to determine the level of dilution that will be used. The data about the characteristics of fresh semen of Gembrong goat collected by using artificial vagina showed that the semen had a good quality and met the requirement for cryopreservation (Table 1). The criteria of fresh semen that can be used for cryopreservation and as a base for determination of male fertility with the very good category must have the percentage of sperm motility $>50 \%$ (Pezzanite et al., 2012), sperm concentration of $2 \mathrm{x}$ $10 \% / \mathrm{mL}$, minimum percentage of sperm viability of $80 \%$, and the percentage of sperm abnormality is not more than 15\% (Tambing et al., 2000).

The volume of semen of Gembrong goat found in this experiment showed a value similar to the previously reported in Ettawah crossed Goat i.e., 0.68 \pm 0.18 $\mathrm{mL}$ (Rizal, 2008). However, the volume of semen found in Gembrong goat in this experiment was lower as compared those reported in Nubian goat $(1.50 \pm 0.50 \mathrm{~mL})$ and Nubian crossed Goat (Nubian x PE) $(1.33 \pm 0.29 \mathrm{~mL})$ (Husin et al., 2007), in the Boer goat $(0.83 \pm 0.29 \mathrm{~mL}$ by Husin et al., 2007 and $0.8 \pm 0.2 \mathrm{~mL}$ by Kostaman \& Sutama, 2006), and in Saanen goat $(1.13 \pm 0.37 \mathrm{~mL})$ (Tambing et al., 2003). The volume of semen found in this experiment was in the normal range i.e., $0.1-1.5 \mathrm{~mL}$ (Jainudeen et al., 2000). Furthermore, Suharyati and Hartono (2013) stated that the volume of semen of Boer goat ranged 0.77-1.13 mL. According to Ax et al. (2000), the volume of semen

Table 1. Characteristics of fresh semen of Gembrong goat

\begin{tabular}{lc}
\hline Parameter & \\
\hline Volume $(\mathrm{mL})$ & $0.5 \pm 0.1$ \\
Color & Creamy and milky \\
Consistency & medium-viscous \\
$\mathrm{pH}$ & $6.4 \pm 0.0$ \\
Sperm concentration $\left(\ldots . . . \times 10^{6}\right)$ & $6,731 \pm 785$ \\
Sperm abnormality $(\%)$ & $5.74 \pm 1.59$ \\
\hline
\end{tabular}

is different according to breed, age, body size, season, feeding level, and the frequency of semen collection.

The results of this experiment showed that the fresh semen of Gembrong goat had a creamy and milky color with a medium to viscous consistency with the sperm concentration of $6,731 \pm 785 \times 10^{6} / \mathrm{mL}$. Some previous studies reported that the color of fresh semen of Ettawah crossed goat was milky white with a consistency a little bit viscous, and sperm concentration of 4,148.57 \pm 198.60 $\mathrm{x} 10^{6} / \mathrm{mL}$ (Rizal et al., 2008). However, Isnaini (2011) reported that the color of fresh semen of Boer goat was turbid white with a consistency of a little bit viscous, and sperm concentration of $3.387 \pm 230.32 \times 10^{6} / \mathrm{mL}$. According to Ax et al. (2000), the color of fresh semen in goat was milky white to creamy, but in Boer goat, the color of semen was white to creamy (Kostaman and Sutama, 2006).

The average $\mathrm{pH}$ of fresh semen of Gembrong goat was 6.4. Some previous reports stated that the $\mathrm{pH}$ of the semen in Ettawah crossed Goat was 6.8 (Yani et al., 2001), Saanen goat was 7.13 \pm 0.24 (Tambing et al., 2003), Nubian goat was 6.67 \pm 0.76 , Nubian Crossed Goat (Nubian x PE) was $6.50 \pm 0.50$, and Boer goat was $6.83 \pm 0.29$ (Husin et al., 2007). The range of semen $\mathrm{pH}$ found in this experiment was in the normal range of 5.9-7.3 that was reported in goat (Garner and Hafez, 2000).

The average of abnormal spermatozoa found in this experiment was $5.74 \pm 1.59 \%$. The result found in this experiment was higher than that reported by Suharyati and Hartono (2013), where the percentage of abnormal spermatozoa in Boer goat was $1.11 \%-2.34 \%$. However, the result found in this experiment was lower than those reported by some previous studies, where the percentage of abnormal spermatozoa in Ettawah crossed Goat was $7.12 \pm 0.93 \%$ (Rizal et al., 2008), Kacang goat was $8.6 \pm 2.4 \%$ (Bintara, 2011), Rayini goat was $9.85 \pm 0.25 \%$ (Zamiri \& Heidari, 2006), Majorera goat was $6.5 \pm 1.2 \%$ (Batista et al., 2009), and Nubian as well as Nubian crossed goats (Nubian x PE) were $12.83 \pm 0.81$ and $12.34 \pm 2.77 \%$, respectively (Husin et al., 2007). Senger (2005) reported that each fraction of semen, both obtained from cauda epididymis and ejaculate, contained abnormal spermatozoa around $5 \%-15 \%$ and the decreased in fertilization capability was occurred when the abnormal sperm morphology was more than $20 \%$. The percentage of abnormal spermatozoa found in this experiment was still in the range of normal value.

\section{The Characteristics of Spermatozoa during Cryo- preservation Process in Gembrong Goat}

The process of cryopreservation strongly affected the characteristics of spermatozoa in Gembrong goat (Figure 1). The results of the experiment showed that the percentages of sperm motility, viability, and membrane integrity of Gembrong goat during cryopreservation process were decrease. After thawing, the percentage of spermatozoa motility decreased significantly $(\mathrm{P}<0.05)$ as compared to those observed in the early stage and at equilibration stage. The percentages of sperm viability and membrane integrity of Gembrong goat during cryopreservation showed a similar pattern to the percentage of progressive motility of spermatozoa. 


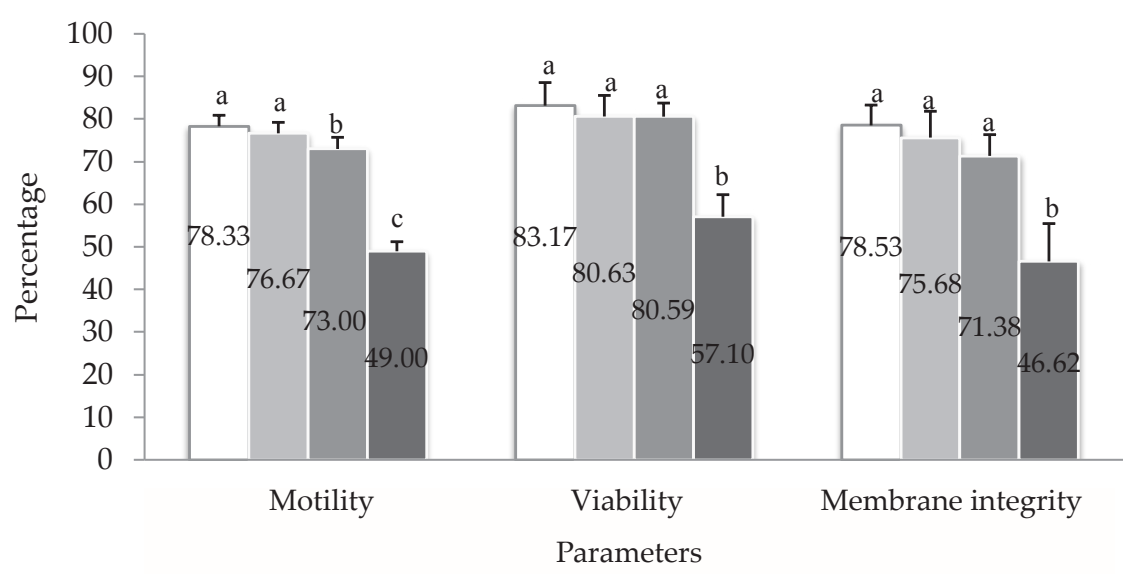

Figure 1. Percentage of sperm motility, viability, and sperm membrane integrity during semen cryopreservation in Gembrong goat. In each stage of cryopreservation, bar with different superscripts $(a, b, c)$ indicated a significant difference $(P<0.05)$. $\square$ Fresh Before Equilibration $\quad$ After Equilibration

- Post Thawing

This result showed that the spermatozoa of Gembrong goat were sensitive to cold shock due to the decreased temperature during cryopreservation process. Spermatozoa experienced cellular, biochemical, and osmotic changes during maturation process in epididymis and after the addition of semen plasma at the time of ejaculation. These changes and a dramatic decrease in membrane lipid composition would affect the biological characteristics of spermatozoa at the time of cryopreservation, the permeability of cryoprotectant, and the changes in plasma membrane phase during cooling and freezing (Yeung et al., 2006).

Cryopreservation could cause the destruction of membrane functions including the increase in membrane fluidity that is worsen by osmotic shock in the membrane that is occurred when the cell experienced an extreme dehydration during the process of cooling and freezing (Shadan et al., 2004). The cryopreservation process causes the decrease in the integrity of the acrosome, the destruction of spermatozoa function and changes in the membrane fluidity, phospholipid and protein aggregation, that are associated with the decrease in enzyme activity, motility, viability, and the ability as well as the capacity to fertilize the ovum (Januskauskas et al., 2003). Hermansson and Axner (2007) reported the decrease in motility and acrosome integrity after thawing. The cooling process in cryopreservation of spermatozoa could suppress metabolic activity of the spermatozoa cells that could decrease energy consumption significantly and cold shock sensitivity that are indicated by the irreversible loss of permeability and integrity of plasma membrane of the spermatozoa that could cause the problem and finally the mortality of the spermatozoa (Guthrie et al., 2011).

The decreases in the percentage of sperm motility and viability, and integrity of sperm membrane during the process of cryopreservation were related to the intracellular changes due to the excretion of water caused by the formation of ice crystal in addition to cold shock. The formation of ice crystals during cryopreservation process of the semen caused the accumulation of electrolytes in the cell that finally caused the destruction of the cell mechanically that eventually affected the metabolism of the spermatozoa. The accumulated electrolyte in the sperm cell would destruct the membrane of spermatozoa so that at the time of thawing, the permeability of sperm membrane would decrease and the spermatozoa would die. The formation of ice crystal could probably be related to the changes in the osmotic pressure in the fraction that did not experience freezing (Watson, 2000).

In addition, at the time of collection and processing of the semen before packing in straw, the spermatozoa have contact with atmospheric air that contains oxygen. This atmospheric contact could cause the increase in oxidative metabolic activity that also causes the increase in free radicals concentration as a product of metabolic process. Free radicals are dangerous to the survival of spermatozoa since free radicals have characteristics that are very reactive to obtain electron by lipid peroxidation reaction. The free radicals will bind and take electron from unsaturated fatty acids in the phospholipids of the cell membrane that could cause chain reaction of lipid peroxidation that can occur continuously (autocatalytic) that finally destruct the whole plasma membrane of the spermatozoa (Holt, 2000).

The percentage of sperm motility after thawing in Gembrong goat was $49.00 \%$ with the viability and membrane integrity of $57.10 \%$ and $46.62 \%$, respectively. The similar result was also reported by Tambing et al. (2003) that average percentage of spermatozoa motility of Saanen goat was $48.33 \%$, and also the percentage of viability and membrane integrity were $58.31 \%$ and $49.05 \%$, respectively. Atessahin et al. (2008) reported the percentage of motility and membrane integrity of spermatozoa in Angora goat after thawing were 51.88\% and $34.43 \%$, respectively. Naijian et al. (2013) reported the percentages of motility, viability, and membrane integrity of spermatozoa of Mahabadi goat after thawing were lower, i.e., $46.20 \%, 51.60 \%$, and $54.59 \%$, respectively. Some previous reports found that the percentage of spermatozoa motility of Florida goat after thawing was $39.94 \%$ (Dorado et al., 2007), Blanca-Celtiberica goat 
was $43.4 \%$ (Rabadan et al., 2012), and San Clemente goat was $40.04 \%$ (Roof et al., 2012).

The results of the experiment showed that after freezing and thawing, the spermatozoa of Gembrong goat was in the best quality condition and meet the requirement for usage in artificial insemination or embryo production in vitro. This good result was related to the high percentage of sperm motility (i.e., $49.00 \pm 2.24 \%$ ). Frozen semen that meets the requirement for artificial insemination must have the percentage of sperm motility at least 40\% (Hafez \& Hafez, 2000).

To obtain a better semen quality in the process of cryopreservation of semen of Gembrong goats, it is recommended to use some methods of cryopreservation with different compositions of extender.

\section{CONCLUSION}

Semen and spermatozoa of Gembrong goats have good quality and meet the requirement for cryopreservation. The characteristics of Gembrong semen are also in the good conditions at the stage of after freezing and after thawing, and meets the requirement for use in artificial insemination or embryo production in vitro.

\section{ACKNOWLEDGEMENT}

This study was funded by Indonesian Center for Agricultural Biotechnology and Genetic Resources (DIPA no. 018.09.2.237221/2013 dated December $5^{\text {th }}$ 2012). Authors would like to thank Imaniyanto from Reproduction Laboratory in Goats Research Station for her technical assistance.

\section{REFERENCES}

Atessahin, A., M. N. Bucak, P. B. Tuncer, \& M. Kizil. 2008. Effects of anti-oxidant additives on microscopic and oxidative parameters of Angora goat semen following the freeze-thawing process. Small. Rum. Res. 77:38-44. http:// dx.doi.org/10.1016/j.smallrumres.2008.03.002

Ax, R. L., M. R. Dally, B. A. Didion, R. W. Lenz, C. C. Love, D. D. Varner, B. Hafez, \& M. E. Bellin. 2000. Semen Evaluation. In: B. Hafez, \& E.S.E. Hafez (eds). Reproduction In Farm Animal. $7^{\text {th }}$ ed. Lippincott \& Wilkins, Philadelphia. p. 365-375.

Bintara, S. 2011. Rasio spermatozoa X:Y dan kualitas sperma pada kambing kacang dan peranakan ettawa. Sains Peternakan 9(2): 65-71.

Batista, M., T. Nino, D. Alamo, N. Castro, M. Santana, F. Gonzalez, F. Cabrera, \& A. Gracia. 2009. Successful artificial insemination using semen frozen and stored by an ultrafreezer in the Majorera goat breed. Theriogenology 71:1307-1315. http://dx.doi.org/10.1016/j.theriogenology.2 008.12.024

Dorado, J., I. Rodriguez, \& M. Hidalgo. 2007. Cryopreservation of goat spermatozoa: Comparison of two freezing extenders based on post-thaw sperm quality and fertility rates after artificial insemination. Theriogenology 68:168-177. http://dx.doi.org/10.1016/j.theriogenology.2007.04.048

Drouineaud, V., P. Sagot, L. Faivre, F. Michel, \& C. Jimenez. 2003. Birth after intracytoplasmic injection of epididymal sperm from a man with congenital bilateral absence of the vas deferens who had a robertsonian translocation. Fertil
Steril 79 (Suppl 3):1649-1651. http://dx.doi.org/10.1016/ S0015-0282(03)00341-8

Garner, D. L. \& E. S. E. Hafez. 2000. Spermatozoa and Seminal Plasma. In: B. Hafez \& E.S.E. Hafez (eds.) Reproduction In Farm Animal. $7^{\text {th }}$ ed. Lippincott \& Wilkins, Philadelphia. p. $96-109$

Guthrie, H. D., G. R. Welch, D. D. Theisen, \& L. C. Woods. 2011. Effects of hypothermic storage on intracellular calcium, reactive oxygen species formation, mitochondrial function, motility, and plasma membrane integrity in striped bass (Morone saxatilis) sperm. Theriogenology 75:951-961. http://dx.doi.org/10.1016/j.theriogenology.2010.10.037

Hafez, E. S. E. \& B. Hafez. 2000. Anatomy of male reproduction. In: B. Hafez \& E.S.E. Hafez (eds.) Reproduction In Farm Animal. $7^{\text {th }}$ ed. Lippincott \& Wilkins, Philadelphia. p. 312 .

Handiwirawan, E., S. A. Asmarasari, \& B. Setiadi. 2007. Panduan karakterisasi ternak kambing dan domba. Pusat Penelitian dan Pengembangan Peternakan. hal 1-39.

Hermansson, U. \& E. Axnér. 2007. Epididymal and ejaculated cat spermatozoa are resistant to cold shock but egg yolk promotes sperm longevity during cold storage at $4{ }^{\circ} \mathrm{C}$. Theriogenology 67:1239-1248. http://dx.doi.org/10.1016/ j.theriogenology.2007.01.008

Husin, N., T. Suteky, \& Kususiyah. 2007. Uji kualitas semen kambing nubian dan peranakannya (kambing nubian $x$ PE) serta kambing boer berdasarkan lama penyimpanan. Jurnal Sain Peternakan Indonesia 2:57-65.

Holt, W. V., T. Abaigar, \& H. N. Jabbour. 1996. Oestrus synchronization, semen preservation and artificial insemination in the Mohor Gazelle (Gazella dama mhorr) for the establishment of a genome resource bank programme. Reprod. Fertil. Dev. 8:1215-1222. http://dx.doi.org/10.1071/RD9961215

Isnaini, N. 2011. Viabilitas spermatozoa kambing Boer pasca pendinginan dan pembekuan menggunakan pengencer dasar Tris dengan level trehalosa yang berbeda. J. Ternak Tropika 12: 27-37.

Jainudeen, M. R., H. Wahid \& E. S. E. Hafez. 2000. Sheep and Goats. In: B. Hafez \& E. S. E. Hafez (eds.) Reproduction In Farm Animal. $7^{\text {th }}$ ed. Lippincott \& Wilkins, Philadelphia.

Januskauskas, A., A. Johannisson, \& H. R. Martinez. 2003. Subtle membrane changes in cryopreserved bull semen in relation with sperm viability, chromatin structure, and field fertility. Theriogenology 60:743-758. http://dx.doi. org/10.1016/S0093-691X(03)00050-5

Kaabi, M., P. Paz, M. Alvarez, E. Anel, J. C. Boixo, H. Rouissi, P. Herraez, \& L. Anel. 2003. Effect of epididymis handling conditions on the quality of ram spermatozoa recovered postmortem. Theriogenology 60:1249-1259. http://dx.doi. org/10.1016/S0093-691X(03)00139-0

Kostaman, T., I. K. Sutama, P. Situmorang, \& I. G. M. Budiarsana. 2000. Pengaruh jenis pengencer dan waktu ekuilibrasi terhadap kualitas semen beku kambing peranakan etawah. Seminar Nasional Peternakan dan Veteriner, Bogor. Hlm 156-163.

Kostaman, T., \& I.K. Sutama. 2006. Studi motilitas dan daya hidup spermatozoa kambing boer pada pengencer tris-sitrat-fruktosa. J. Sain. Vet. 24(1):58-64.

Martins C. F., R. Rumpf, D. C. Pereira, \& M. N. Dode. 2007. Cryopreservation of epididymal bovine spermatozoa from dead animals and its uses in vitro embryo production. Anim. Reprod. Sci. 101:326-331. http://dx.doi.org/10.1016/ j.anireprosci.2007.01.018

Naijian, H. R., H. Kohram, A. Z. Shahneh, \& M. Sharafi. 2013. Effects of various concentrations of BSA on microscopic and oxidative parameters of Mahabadi goat semen following the freeze-thaw process. Small. Rum. Res. 113:371-375. http://dx.doi.org/10.1016/j.smallrumres.2013.03.015

Oka, I. G. L., W. S. Yupardhi, I. B. Mantra, N. Suyasa, \& A. A. S. 
Dewi. 2011. Genetic relationship between gembrong goat, kacang goat and kacang $x$ etawah crossbred (PE) based on their mitochondrial DNA. Jurnal Veteriner 12:180-184.

Pezzanite, L., A. Bridges, M. Neary, \& T. Hutchens. 2012. Breeding Soundness Examinations of Rams and Bucks. http://www.extension.purdue.edu/extmedia/AS/AS-599W.pdf [27 Januari 2012].

Purdy, P. H. 2006. A review on goat sperm cryopreservation. Small. Rum. Res. 63:215-225. http://dx.doi.org/10.1016/j.s mallrumres.2005.02.015

Rabadan, P. J., M. Ramon, O. G. Alvarez, A. M. Morales, E. D. Olmo, M. D. P. Guzman, A. Bisbal, M. R. F. Santos, J. J. Garde, \& A. J. Soler. 2012. Effect of semen collection method (artificial vagina vs. electroejaculation), extender and centrifugation on post-thaw sperm quality of BlancaCeltibérica buck ejaculates. Anim. Reprod. Sci. 132:88- 95. http://dx.doi.org/10.1016/j.anireprosci.2012.04.005

Rizal, M., Herdis, M. Surachman, \& W. M. M. Nalley. 2008. Pengaruh plasma semen domba Priangan terhadap daya hidup spermatozoa kambing Peranakan Etawah yang disimpan pada suhu $3-5^{\circ} \mathrm{C}$. JITV 13: 23-29.

Roof, D. J., S. Bowleya, L. L. Pricec, \& D. J. Matsasa. 2012. Comparison of two commercial extenders for cryopreservation of goat semen without sperm washing. Theriogenology 77:412-420. http://dx.doi.org/10.1016/j.theriogenology.201 1.08 .015

Senger, P. L. 2005. Pathways to Pregnancy and Parturition. $2^{\text {nd }}$ Revised Edition. Washington: Current Conceptions. Inc.

Shadan, S., P. S. James, E. A. Howes, \& R. Jones. 2004. Cholesterol Efflux Alters Lipid Raft Stability and Distribution During Capacitation of Boar Spermatozoa. Biol. Reprod. 71:253-265. http://dx.doi.org/10.1095/biolreprod.103.026435
Steel, R. G. D., \& J. H. Torrie. 1993. Prinsip dan prosedur statistika: suatu pendekatan biometrik. Alih Bahasa: B. Sumantri. Gramedia Pustaka Utama, Jakarta.

Suharyati, S. \& M. Hartono. 2013. Peningkatan kualitas semen kambing Boer dengan pemberian vitamin E dan mineral Zn. Jurnal Kedokteran Hewan 7:91-93.

Tambing, S. N., M. R. Toelihere, T. L. Yusuf, \& I. K. Sutama. 2000. Pengaruh gliserol dalam pengencer Tris terhadap kualitas semen beku kambing Peranakan Etawah. JITV 5:1-8.

Tambing, S. N., M. R. Toelihere, T. L. Yusuf, B. Purwantara, I. K. Sutama, \& P. Situmorang. 2003. Kualitas semen beku kambing saanen pada berbagai jenis pengencer semen. Hayati 10:146-150.

Watson, P. F. 2000. The causes of reduced fertility with cryopreserved semen. Anim. Reprod. Sci. 60:481-492. http:// dx.doi.org/10.1016/S0378-4320(00)00099-3

Yani, A., Nuryadi, \& Pratiwi. 2001. Pengaruh tingkat substitusi santan kelapa pada pengencer tris dan waktu penyimpanan terhadap kualitas semen kambing Peranakan Ettawah (PE). Jurnal Biosain 1:23-29.

Yeung, C. H., J. P. Barfield, \& T. G. Cooper. 2006. Physiological volume regulation by spermatozoa. Mol. Cell. Endocrinol. 250:98-105. http://dx.doi.org/10.1016/j.mce.2005.12.030

Zamiri, M. J. \& A. H. Heidari. 2006. Reproductive characteristics of Rayini male goats of Kerman province in Iran. Anim. Reprod. Sci 96:176-185. http://dx.doi.org/10.1016/ j.anireprosci.2005.12.002

Zein, M. S. A., S. Sulandri, Muladno, Subandriyo \& Riwantoro. 2012. Diversitas genetik dan hubungan kekerabatan kambing lokal Indonesia menggunakan marker DNA mikrosatelit. JITV 17: 25-35. 